\title{
NU DAN PARADIGMA TEOLOGI POLITIK PEMBEBASAN: REFLEKSI HISTORIS PASCA KHITTTAH
}

\author{
Muhammad Masyhuri \\ Dosen Institut Agama Islam Syarifuddin (IAIS) Lumajang \\ JL. Pondok Pesanten Kyai Syarifuddin Wonorejo Lumajang Jatim,Indonesia \\ E-mail: muhamasyhur@gmail.com
}

\begin{abstract}
This research means to study the religious institution's role to liberate from the problems of ummah in their real life. Theological study on dimension of liberation here aims to investigate what are Muslim scholars' opinions on this issue and how to implement their thought on political reality. This study employs historical description focuses on historical dynamic of Nahdlatul Ulama (NU) political position and its institution, especially after returning to the khittah of 1926. This study also analyzes those dynamics in relation to liberation theology. This study shows that institutional dynamic of NU in politic and its reflection, be it is in accommodatif respond or opposition, related to its stands between religion and the state is strongly inspired from Sunni political paradigm. However, there have been some variation related to sociological politic in implementing this Sunni paradigm in reality. Institutionally, the implementation to reflect liberation theology can be identified as substantialistic, realistic and rationalistic. The root of liberation on theology in NU can be seen from its emphasis on the issues of peace, pluralism, humanity and justice. By implementing this liberation of theology, there are some changes in the dynamic of NU history in the forms of growing number of educational institution, strengthening religious' roles and positions, increasing community participation in social, economic and politic without confounding with institutional religious politisation.
\end{abstract}

Keywords:

Nahdlatul Ulama; social change; politic; liberation theology.

\begin{abstract}
Abstrak
Kajian ini bertujuan untuk melihat peran institusi agama dalam upaya membebaskan umat dari dilema yang dihadapinya. Kajian teologis dalam dimensi pembebasan ini selain bertujuan untuk melihat bagaimana ijtihad para ulama dalam merefleksikan doktrin keagamaan atas dilema politik yang terjadi juga melihat bagaimana strategi yang digunakan dalam mengimplementasikan kedalam realitas politik yang dihadapi. Kajian ini bersifat historis deskriptif yang terfokus pada aspek kesejarahan dinamika politk NU, aspek kelembagaan setelah kembali ke khittah 1926, juga menganalisis dinamika tersebut dengan mengkaitkan konsep teologi pembebasan dalam Islam. Hasil kajian menunjukkan bahwa dinamisasi kelembagaan NU dalam politik serta refleksinya-baik berbentuk akomodasi maupun oposisi dalam memaknai hubungan antara agama dan negara- terkait erat dengan paradigma politik Sunni. Meski dalam kenyataannya, memunculkan varian sosiologis politik yang beragam dalam memaknai paradigma teologi Sunni tersebut. Namun secara kelembagaan, implementasi refleksi teologi pembebasan yang terlihat lebih pada bentuk substansialistik, realistik dan rasionalistik. Akar pembebasan secara teologis di NU terlihat dalam varian ini yang lebih menekankan pada perdamaian, pluralisme, kemanusiaan dan keadilan. Perubahan yang terjadi dalam dinamika sejarah NU adalah berkembangnya institusi pendidikan, menguatnya peran dan posisi keagamaan, serta meningkatnya partisipasi masyarakat dalam bidang sosial ekonomi dan politik tanpa terjebak pada politisasi agama secara kelembagaan.
\end{abstract}

Kata Kunci:

Nahdlatul Ulama; perubahan sosial; politik; teologi pembebasan.

DOI: http://dx.doi.org/10.15575/jw.v1i2.727

Received: March 2016 ; Accepted: August 2016 ; Published: August 2016 


\section{A. PENDAHULUAN}

Nahdlatul Ulama (NU) merupakan organisasi sosial keagamaan yang menjadi wadah bagi kalangan muslim tradisional Indonesia di mana keberadaanya sering diidentikkan dengan kelompok konservatif-ortodoks. Meskipun demikian, sebagai organisasi Islam terbesar di Indonesia, NU juga dihadapkan dengan berbagai dinamika persoalan yang menuntut untuk dapat melakukan adaptasi agar keberlanjutan organisasi ini dapat tetap dipertahankan. Proses adaptasi tersebut telah banyak ditulis oleh para sejarawan yang menggambarkan bagaimana dinamisasi tersebut hadir, baik sejak awal berdir inya hingga perkembangannya. Meskipun para ulama tradisionalis mendasarkan tradisinya pada pola konservatisme yang terkesan jumud dan sulit berubah, namun mereka tetap merasa perlu mengemukakan bahwa NU dimunculkan sebagai wadah perjuangan bagi kelompok masyarakat muslim tradisional dalam upayanya untuk menyelesaikan persoalan yang dihadapi umat Islam di lndonesia. Pengaruh tekanan penjajahan kolonial Barat, tekanan negara yang represif, serta arus modernisasi dan globalisasi yang memunculkan perubahan kearah pembaharuan namun disisi lain juga menjadi tantangan serius bagi kelompok ini baik dalam aspek ekonomi, kebudayaan serta aspek keagamaan. Untuk kepentingan ini, para ulama berupaya melakukan ijtihad politik dengan melakukan interpretasi atas ajaran agama agar dapat terbentuk suatu kondisi yang maslahat bagi umat di mana hal ini pada akhirnya menjadi bentuk upaya pembebasan bagi masyarakat Islam di Indonesia secara umum. ${ }^{1}$

Pembaharuan untuk melakukan perubahan dan penyesuaian terhadap kondisi tersebut ditandai dengan munculnya beberapa refleksi atas prinsip dan doktrin ajaran keagamaan yang selama ini mereka yakini. Salah satu bentuk refleksi ini adalah munculnya perubahan dalam paradigma gerakan kultural ke ranah politik praktis pada awal-awal kemer-

\footnotetext{
1 Said Agil, NU dan Masalah Kebangsaan (Jakarta: Pustaka Ciganjur, 1998).
}

dekaan. Karena demikian, beberapa kalangan memandang ranah refleksi atas doktrin di NU lebih banyak terealisasikan dalam aspek politik -di mana hampir tiga puluh tahun- NU terlibat langsung dalam konstalasi politik. Namun perubahan terjadi setelah Muktamar ke-28 di Situbondo 1984 diselenggarakan, di mana NU menegaskan diri untuk kembali ke Khittah 1926 yang menegaskan untuk tidak menjadi bagian dari politik praktis secara kelembagaan. ${ }^{2}$

Dalam konteks lain, tradisi dan kebudayaan yang berkembang dikalangan NU juga dipandang banyak kalangan sebagai bentuk dari konservatisme-ortodoks yang mengesankan pada antisipasi terhadap perubahan dan mengungkung diri kepada kejumudan terutama pada tradisi keagamaan. Bentuk-bentuk konservatisme tersebut muncul dalam berbagai bentuk, seperti halnya dalam pendidikan pesantren, berkembangnya mistik Islam seperti model tarekat yang ada dalam Jam'iyah ahl al-Tariqah al-Mu'tabarah al-Nahdiyah, serta beberapa bentuk tradisi-tradisi lain yang banyak berkembang seperti perayaan dan ritual yang terkait dengan kematian (tahlilanyasinan, haul, istighathah) yang saat ini tetap menjadi tradisi yang di pandang penting oleh masyarakat muslim tradisionalis ini. $^{3}$ Meskipun demikian, dalam dinamika sejarah perpolitikan NU terdapat dinamisasi dan proses adaptasi yang menunjukkan terhadap upaya pembebasan ini.

Keberadaan tradisi yang berkembang di kalangan NU selain sering diidentikkan dengan konservativisme- yang sangat kental dengan stagnasi dan keterikatannya pada nilai tradisi lama, namun disisi lain justru menjadi paradigma gerakan yang mencerminkan munculnya dimensi pembebasan yang secara efektif dapat digunakan dalam mencapai tujuan keagamaan yang ideal. Hal ini ditandai dengan adanya refleksi atas doktrin dan norma keagamaan yang digunakan

\footnotetext{
2 Mohammad A.S. Hikam, Fiqh Kewarganegaraan, Intervensi agama-negara terhadap masyarakat Sipil (Jakarta: PBPMII, 2001), 87.

${ }^{3}$ M. Dawam Raharjo, Pesantren dan Pembaharuan (Jakarta: LP3ES, 1987), 17.
} 
dalam memahami dinamika politik organisasi ini seperti yang muncul dalam Muktamar dan forum bahthul masāil yang sering dikembangkan dalam tradisi keagamaan di NU. Berdasarkan hal tersebut, permasalahan yang saat ini masih menjadi polemik dan perlu dikaji adalah bagaimana pengaruh konservatisme keagamaan tersebut terhadap dimensi perpolitikan NU terutama setelah kembali ke Khittah 1926.

Berdasarkan latar belakang tersebut, terdapat sejumlah pertanyaan yang perlu dikembangkan dalam pembahasan tentang ini, diantaranya adalah bagaimana kemudian NU sebagai institusi berpartisipasi dalam perpolitikan setelah kembali ke Khittah 1926 (1984-2001) apa yang terjadi dalam konstalasi perpolitikan nasional setelah NU kembali ke Khittah 1926. Serta bagaimana adaptasi kelembagaan yang dilakukan NU dalam menyikapi dinamika politik tersebut? Khususnya adaptasi di bidang doktrin, kepemimpinan dan program. Selain itu pertanyaan yang mendasar berkaitan dengan ini adalah bentuk refleksi teologis $\mathrm{NU}$ atas dinamika perpolitikan tersebut yang dapat dikategorikan sebagai dimensi yang sesuai dengan tujuan keagamaan, sehingga sesuai dengan prinsipprinsip yang membebaskan dalam konteks agama Islam.

Berdasarkan permasalahan di atas, kajian ini berupaya untuk melihat bagaimana perspektif teologi pembebasan muncul dari dinamika persoalan tersebut. Berkaitan dengan ini, hal mendasar tentang perbedaan teologis dalam paradigma teologi pembebasan bermula dari refleksi atas persoalan nyata yang terjadi. Teologi pembebasan dipahami sebagai sebuah paradigma berteologi yang didasarkan pada dimensi realitas praksis-reflektif teologis, kemudian melahirkan praksis baru (newpraksis). ${ }^{4}$ Dalam hal ini, dinamika praksis yang menghasilkan reflektif ajaran agama akan muncul pada uraian pertanyaan pertama - partisipasi NU sebagai sebuah institusi setelah kembali ke Khittah 1926.

\footnotetext{
${ }^{4}$ Wahono Nitiprawiro, Teologi Pembebasan, Sejarah, Metode, Prakis dan isinya (Yogyakarta: LKiS, 2000).
}

Berkaitan dengan ini, dalam beberapa literatur disebutkan bahwa Nahdlatul Ulama (NU) merupakan organisasi Islam terbesar saat ini yang banyak memberikan corak warna dalam kehidupan beragama dan berbangsa di Indonesia. Kajian dan penelitian tentang organisasi ini juga telah menarik perhatian para ilmuwan untuk membincangkan lebih dalam. Para ilmuwan tersebut diantaranya Martin van Bruinessen, Andree Feillard, Sydney Johnes serta Greg Fealey. Kajiankajian mereka secara umum memfokuskan pada dinamika sosial keagamaan dan politik di Nahdlatul Ulama dari sudut pandang teoretisasi sosial. Meskipun demikian, secara umum, kajian mereka tentang NU yang terfokus dalam bingkai 'Teologi Pembebasan' masih belum dilakukan secara mendalam. Misalkan Greg Fealey yang banyak membahas tentang Ijtihad Politik ulama NU dalam kurun waktu 1952-1957, meskipun ia sedikit membahas tentang doktrin NU yang terkait dengan dinamika politik pada waktu itu, namun ia tidak mengkaitkan hal tersebut dengan tema teologi pembebasan. ${ }^{5}$

Begitu pula dengan kajian yang dilakukan oleh Martin, ia banyak menulis tentang dinamika tradisi keagamaan di NU serta menyinggung hubungan yang telah dilakukan NU dengan Negara. ${ }^{6}$ Sementara Andree Feelard dan Sydney Johnes juga banyak membahas dinamika NU pada perkembangan sejarah terutama berkaitan dengan dimensi keagamaan dan politik. Dari beberapa kajian tersebut, tema-tema tentang teologi pembebasan dalam NU masih belum dibahas secara khusus bila dihubungkan dengan tema teologi pembebasan. Sementara di sisi lain, NU sebagai organisasi keagamaan memiliki dimensi yang erat dengan aspek-aspek pembebasan yang ditandai dengan dinamisasi refleksi teologis atas dinamika praksis.

Diskursus teologi pembebasanan sendiri muncul dengan tujuan untuk melihat peran agama dalam melakukan upaya pembebasan

\footnotetext{
${ }^{5}$ Greg Fealey, Ijtihad Potitik Ulama NU, 1952-1967 (Yogyakarta: LKiS, 1998).

${ }^{6}$ Martin van Bruinessen, NU Tradisi Relasi Kuasa, pencarian Wacana Baru (Yogyakarta: LKiS, 1999).
} 
yang dilakukan setiap manusia dalam menghadapi permasalahan yang menyertainya. Wacana pembebasan ini menjadi bagian yang tidak terpisahkan di tiap dinamika sejarah agama manapun termasuk yang arkhais (agama kuno), di mana dua sisi keberpihakan antara penindasan, diskriminasi, ketidakadilan dan sisi pembebasan, keadilan menjadi pilihan dari dinamika tiap agama-baik pada aspek, institusi-organisasi, individu maupun kelompok masyarakatnya. ${ }^{7}$ Begitu juga dalam dinamika kesejarahan Islam, bagi kalangan orientalis Barat, Islam sering diidentikkan dengan pola fundamentalisme dalam menerapkan ajaran keagamaaannya, bahkan juga terorisme, namun dalam fakta kesejarahannya, Islam sangat kental dengan dimensi pembebasan, yang menjunjung tinggi nilai-nilai kemanusian, keadilan dan kesetaraan sebagaimana yang dicontohkan oleh Nabi Muhammad baik di Makkah maupun di Madinah.

Dalam konteks modern, beberapa kajian teologi pembebasan dalam literatur menyebutkan tentang prinsip atas gerakan pembebasan dalam dinamika perjuangan agar sesuai dengan tujuan keagamaan yang berpihak kepada keadilan, kesetaraan, dan mendasarkan kepada dimensi kemanusiaan. Kajian tentang ini pada mulanya berkembang dalam studi kritis tentang masyarakat Amerika Lat in dalam menghadapi tekanan represif baik dari negara maupun kelompok elit yang memihak pada kaum pemodal. Sebagai upaya perlawanan, pemunculan interpretasi baru atas ajaran agama oleh para tokoh agama dari kelompok masyarakat tertindas untuk menghadapi ketidakadilan pun dilakukan. Melalui reformasi institusi agama serta reinterpretasi pada teks kitab suci dalam memunculkan teologi perjuangan juga dikembangkan. ${ }^{8}$ Upaya untuk melihat kembali pemahaman atas peran agama agar sesuai dengan dimensi praksis pembebasan juga terlihat dalam

\footnotetext{
7 Michael Amalados, Michael Amalados, Teologi Pembebasan (Yogyakarta: Insist Press, 2001), 5-7.

${ }^{8}$ Enrique Dussel, "a History of the Church in Latin America." In Selected Reading on Liberation Theology, by Kenneth R. Hall, 29. (Yogyakarta: CRCS, 2003).
}

dinamika Sangha Buddism di Srilanka, di mana perlunya keterlibatan institusi agama dalam dinamika politik praktis memunculkan perlawanan bagi kelompok pemerintah diktator yang merugikan pada sebagian besar masyarakat, perubahan dari anti-politik praktis berubah ke wadah politik memunculkan perubahan dalam melihat peran agama dalam dunia praksis. ${ }^{9}$ Dengan demikian, secara mendasar, peran agama-baik dalam mendukung pembebasan atau melindungi ketidakadilan - selalu mewarnai dinamika sejarah tiap agama.

Dalam sejarahnya, kajian teologi pembebasan merupakan studi kritis tentang fenomena sosial yang telah banyak dikembangkan para ilmuwan sosial dalam mengkaji studi agama dan perubahan sosial. Di antara contoh kajian tersebut adalah studi teologi pembebasan yang di kaji oleh Joseph M. Wilson dan Berry Man yang berupaya mengurai hubungan agama dengan revolusi sosial di Amerika Latin. Selain itu juga ada studi tentang Black American theology yang dikaji oleh James $H$. Cone, yang mengurai dukungan organisasi keagamaan dalam melawan ketidakadilan dan otoriter negara. Studi dengan perspektif ini dalam perkembangannya mulai bermunculan dengan pendekatan keadilan sosial dan upaya penghapusan diskriminasi seperti kajian tentang Black Moslem theology di Amerika yang dikaji oleh Crayson Lyod dan James C Scott yang memfokuskan pada upaya perjuangan petani Muslim dalam melakukan perlawanan dengan pemilik modal dan kebijakan pemerintah. ${ }^{10}$ Dari beberapa hasil kajian-kajian tersebut, secara mendasar studi dalam perspektif teologi pembebasan melihat peran agama dalam menciptakan perubahan sosial agar sesuai dengan dimensi kemanusian. Dengan maksud yang sama, bagaimana ajaran suatu agama dalam melihat dunia sosial yang terjadi agar menjadi solusi bagi manusia secara

\footnotetext{
9 Stanley Jeyaraja Tambiyah, Buddhism-Betrayed: Religion-Politic and Violence in Sri Lanka. (Chicago: University of Chicago Press, 1990).

${ }^{10}$ James. C. Scott, Senjatanya Orang-orang yang Kalah
} (Jakarta: Obor, 2000). 
keseluruhannya. Hal ini didasarkan atas asumsi bahwa dimensi agama seringkali tereduksi oleh kepentingan manusia sehingga menjadi statis dan memihak kepada kekuasaan yang represif dan otoriter.

Berkaitan dengan tema teologi pembebasan ini, khususnya Islam dan teologi pembebasan yang ada di Indonesia, secara spesifik akan melihat bagaimana peran NU sebagai institusi dalam upayanya merealisasikan tujuan keagamaannya. Kajian ini menjadi penting karena selain dapat melihat peran NU secara kelembagaan dalam merefleksikan doktrin keagamaannya juga dapat melihat secara dekat hubungan antara dimensi praksis politik dengan dimensi doktrin teologis yang ada di NU terutama setelah kembali ke Khittah 1926 (1984-2001).

Selain itu, studi ini juga dapat memahami bagaimana refleksi atas doktrin yang terpola dalam praksis baru dalam dinamisasi kelembagaan di NU dirumuskan. Sehingga secara teologis, dari studi ini dapat diketahui karakter perilaku politik yang dimunculkan oleh paradigma politik NU - di mana hal tersebut juga dapat mengetahui beberapa tipologi refleksi yang muncul dalam dinamika praksis politik dalam kurun waktu 1984-2001. Dengan kesimpulan yang sama, kajian ini juga bisa melihat rumusan orientasi teologis dalam aspek politik yang diperjuangkan NU, terutama dalam memaknai hubungan antara agama, masyarakat dan negara.

\section{B. HASIL DAN PEMBAHASAN \\ 1. Perubahan Sosial dan Dimensi Pembe- basan dalam Islam}

Islam merupakan agama yang membawa misi perubahan dari berbagai simbol dan kondisi manusia yang jahiliyah, terkungkung, tertindas, terhegemoni agar menjadi manusia yang bertauhid, dan merdeka sebagaimana yang dicontohkan oleh Nabi Muhammad. Misi tauhid merupakan pilar utama dalam perubahan ini, karena ajaran agama yang telah diinterpretasikan dalam kehidupan nyata seringkali tidak berkesesuaian dengan maksud utama dari ajaran agama tersebut diturun- kan seperti adanya keadilan, kesetaraan, dan membebaskan dari segala bentuk dan simbol penindasan. Agama Islam sendiri, sebagaimana disebutkan Ali Asghar, merupakan seperangkat doktrin spiritual dan metafisika yang mengikat pemeluknya, memiliki ritual ibadah, yang membentuk sense of identity untuk menjadi pandangan hidup bagi penganutnya dalam mencari solusi bagi semua persoalan di dunia yang dihadapinya. Meski demikian, dalam perkembangannya, proses pencarian solusi untuk menemukan kebenaran dalam hidup tersebut terhambat dengan cara pandang yang merubah akan tujuan agama itu sendiri, karena terpengaruh dengan berbagai kepentingan dan kubutuhan duniawi, ditambah pula doktrin dan ritual agama menjadi pelipur lara semata (a sense of symbolic fulfilment), karena telah mengkristal menjadi dogma yang kaku dan tidak sesuai dengan konteks yang terjadi. ${ }^{11}$

Kenyataan ini dalam perkembangannya juga ditambah dengan kurangnya daya kritis kalangan intelektual. Dengan menjadikan agama hanya sebatas obyek kajian metafisika yang abstrak, tidak menyentuh pada dimensi persoalan eksistensial kemanusiaan yang dihadapinya. Karena demikian, dalam konteks ini agama hanya sebatas latihan intelektual murni yang tidak menjadi wadah dalam upayanya untuk mendekatkan dirinya kepada Tuhan, sebaliknya agama menjadi pemisah antara dirinya dengan kebutuhan riil dalam konteks dinamika sosial yang terus berubah. Sebagai akibatnya, agama pada akhirnya menjadi seperangkat ritual ibadah yang kering (set of dead ritual) bagi penganutnya. Di sisi yang lain, agama menjadi seperangkat konsep atas doktrin yang abstrak dan rumit untuk dapat dipahami. Karena demikian, agama dalam konteks ini menjadi sesuatu yang jumud karena tidak menjadi kode etik atau aturan moral yang dinamis. Dalam konteks ini pula agama tidak mampu menjadi pedoman bagi penganutnya sehingga kehidupan spiritualitasnya menjadi kering karena tidak memiliki dimensi makna yang akhirnya tidak mampu meyelesaikan pro-

\footnotetext{
${ }^{11}$ Asghar Ali Engginer, Islam dan Teologi Pembebasan (Yogyakarta: Pustaka Pelajar, 1999), 8.
} 
blem-problem eksistensial kemanusiaan yang terjadi. ${ }^{12}$ Berkaitan dengan persoalan dalam keagamaan ini, Asghar menyebutkan bila agama tidak dapat berfungsi sebatas menjadi pelipur lara dan hanya sebatas obyek kajian intelektualitas semata, maka agama harus mampu bertransformasi untuk melakukan perubahan sosial. Interpretasi atas ajaran agama perlu ditransformasikan ke dalam kehidupan nyata agar lebih kontekstual dan secara aktif mendorong terciptanya perubahan atas tatanan sosial yang up to date. Fungsi agama sebagai legitimasi atas mekanisme sosio-political and economy yang menguntungkan status quo, kelas penguasa, dan kelas sosial perlu dirubah menjadi dimensi pembebas akan terciptanya kondisi sosial yang membebaskan tersebut. Hal inilah yang tercermin dalam sejarah awal mula Islam di mana peran Nabi Muhammad selain mampu membebaskan masyarakat saat itu dari mitos, pemberhalaan dan budaya menindas, tapi juga mendorong para pengikutnya untuk mampu membebaskan diri dari ketertindasan dan keterpinggiran secara sosial dan ekonomi oleh para penguasa Quraisy saat itu. Himpitan ekonomi karena penindasan dari para rentenir, kapitalis, dan tekanan represif dari penguasa saat itu dapat bebaskan melalui pemahaman dan pengamalan agama Islam yang benar.

Pemahaman tentang ajaran Islam yang membebaskan ini didasarkan atas konsep tauhid yang bersifat antropho-sentris, kongkrit dan menyentuh dimensi kemanusiaan. Pemahaman ini berbeda dengan pemahaman teologi yang bersifat abstrak, theosentris, dan metafisik yang kaku dan jumud. Doktrin tauhid la ilaha illa Allah, tiada tuhan selain Allah harus menjadi doktrin liberatif yang membebaskan, bukan doktrin yang mengkungkung dan stagnan. Dimensi Pembebasan dalam Islam sendiri juga berhubungan dengan lima prinsip dasar dalam pensyariatan hukum Islam (usus alkhamsah), lima prinsip dasar tersebut adalah; 1. Hifzu al- din; kemerdekaan untuk beragama 2. Hifzu al-nasl; kemerdekaan untuk memperoleh keturunan, 3. Hifzu al-aql; kemerdekaan untuk berfikir, 4. Hifžu al-mal; kemerdekaan

\footnotetext{
${ }^{12}$ Asghar, Islam dan Teologi Pembebasan, 9.
}

untuk memperoleh harta benda, 5 Hifzu alnafs; kemerdekaan untuk hidup.

Pembebasan yang didasarkan pada dimensi tauhid juga diartikan oleh Hasan Hanafi berkaitan dengan implikasi terhadap dua tindakan mendasar. Tindakan peniadaan yang didasarkan pada kalimat "la ilaaha illa Allah" dimaksudkan pada peniadaan seseorang dari pembebasan manusia dari segala bentuk penindasan, pemaksaan, otoritarianisme, dan kekejaman. Sementara kalimat syahadat kedua "Muhammad Rasulullah", Nabi Muhammad adalah utusan Allah, berimplikasi sebagai sebuah pernyataan tentang kesempurnaan wahyu yang tercipta dalam sistem sosial yang bernama negara. Dengan demikian, mengindahkan kalimat tauhid, atau syirik, berarti juga tidak sekedar menyekutukan Allah saja, namun lebih dari itu, penguasaan manusia atas manusia yang lain. Dalam skala sosial yang lebih luas, selama ada kesenjangan antara orang kaya dan orang miskin, adanya golongan penindas dan yang tertindas, maka selama itu pula masyarakat dihadapkan pada kondisi yang diliputi kemusyrikan. ${ }^{13}$

Hubungan antara masyarakat dan negara dalam Islam tercermin dalam konsep keadilan yang menjadi posisi penting menciptakan hubungan yang kondusif dalam suatu negara. Berkaitan dengan ini, Ibn Taimiyah menyebutkan bahwa keadilan dalam Islam memiliki posisi sentral karena kehidupan manusia akan menjadi lebih baik dan tertata, meskipun manusia diliputi oleh perbuatan dosa. Hal ini juga yang menjadi alasan mengapa negaranegara yang menjunjung tinggi keadilan dan menerapkannnya menjadi lebih baik meskipun dipimpin oleh non-muslim. Karena demikian, hal ini juga dapat diartikan bahwa dunia akan dapat bertahan dengan keadilan meskipun diiringi kekufuran, sebaliknya tidak dapat bertahan dengan tidak adanya keadilan meski dengan Islam. ${ }^{14}$ Dalam agama Islam, keadilan harus diwujudkan di semua aspek kehidupan. Meskipun demikian, keadilan tidak akan terwujud tanpa adanya pembebasan kelompok

\footnotetext{
${ }^{13}$ Eko Prasetyo, Islam Kiri (Yogyakarta: Insist Press, 2003).

${ }^{14}$ Prasetyo, Islam Kiri.
} 
marjinal dan lemah dari penderitaan, serta memberikan kesempatan bagi mereka untuk menjadi pemimpin.

\section{Dinamisasi NU dalam Menghadapi Peru- bahan Sosial}

\section{a. Dinamisasi Kepemimpinan NU: Dari} Khalid, Wahid dan Hasyim

Dinamisasi kelembagaan di NU ditandai dengan munculnya adaptasi struktural kelembagaan. Bermula dari kesepakatan pada Muktamar Situbondo (1984), di mana NU secara formal kelembagaan menyatakan tidak terkait dengan partai politik manapun. Selanjutnya kesepakatan tersebut memiliki konsekuensi kembalinya NU kepada gerakan sosial keagamaan sebagaimana pada awal NU di dirikan pada tahun 1926. Kesepakatan Situbondo ditandai dengan munculnya kepemimpinan baru yang mewakili kalangan muda, yakni naiknya Abdurrahman Wahid sebagai ketua umum tanfiziyah menggantikan K.H Idham Khalid. ${ }^{15}$

Kesepakatan Situbondo tidak merubah pola struktur organisasi ini, pemimpin tertinggi masih dipegang oleh Syuriah, yang terdiri dari kalangan ulama, sedangkan Tanfidziah berfungsi sebagai pelaksana harian yang melaksanakan ide dan ketetapan umum dari Syuriah. KH. Ahmad Shiddiq dalam muktamar ini menjadi Rais Am di posisi shuriyah, sedangkan Abdurrahman Wahid menempati posisi ketua umum di tanfiziyah. Beberapa kalangan muda juga mulai muncul dari hasil keputusan 'ahl halli wa al-aqd dari Muktamar ini, seperti Mahbub Djunaidi dan Fahmi Syaifuddin yang menempati posisi wakil ketua tanfiziyah, dan Said Budairi sebagai Bendahara, sedangkan Kiai Sahal Mahfudz dan Tolhah Hasan membantu KH. Ahmad Shiddiq di dalam Shuriyah.

Meskipun dari pola struktur organisasi tersebut tidak berubah, namun yang menarik untuk dilihat adalah perubahan kepemimpinan tersebut menjadi indikator awal bagi perubahan orientasi gerakan NU yang akan dilakukan lima tahun kemudian. Bagi beberapa kalangan, perubahan tersebut juga menjadi indikator adanya pengaruh dari hubungan NU dengan kondisi praksis politik yang terjadi (Tebuireng 1984). Di mana ada beberapa kecenderugan yang dapat dilihat sebagai faktor yang mempengaruhi konstalasi politik NU secara makro, seperti adanya keterkaitan dengan upaya pemerintah terhadap penerapan kebijakan unifikasi ideologi ormas kepada Pancasila, serta keterkaitan dengan munculnya pandangan secara umum bahwa gerakan politik praktis di NU dinilai tidak menguntungkan NU baik secara kelembagaan maupun secara personal. Oleh karenanya, hal tersebut kemudian memunculkan dorongan dari kalangan muda yang menghendaki perubahan orientasi gerakan di NU dari gerakan politik praktis ke arah gerakan kultural keagamaan.

Orientasi kembali ke posisi gerakan kultural keagamaan berarti memposisikan NU sebagai organisasi keagamaan yang netral, dengan konsekuensi tidak berfusi dengan PPP sebagaimana periode sebelumnya. Netralitas tersebut juga berarti tidak adanya posisi struktural dalam partai politik dan NU secara bersamaan. Pengurus NU yang aktif dipartai politik diharuskan memilih salah satu posisi struktural yang dikehendakinya. Pilihan tersebut merupakan langkah serius yang dilakukan NU dalam memaknai kesepakatan Khittah 1926 dalam lingkungan NU secara kelembagaan. Walaupun pada awal mulanya penghapusan dualisme struktural bersifat himbauan, namun pada tahap selanjutnya PBNU mengeluarkan kebijakan organisasi berupa SK no 72 /A-II/04-d/XI/85, 26 Oktober 1985. Berdasarkan SK tersebut, dengan jelas bersifat mempertegas Surat Keputusan pertama yang diinstruksikan untuk memisahkan pengurus NU yang memiliki posisi struktural di partai politik. ${ }^{16}$

Dampak langsung dari kebijakan tersebut adalah banyaknya politisi NU di daerahdaerah yang harus rela kehilangan posisi struktural mereka di partai politik khusunya PPP, karena pada waktu itu masih banyak kalangan NU yang tetap berfusi ke PPP sebagaimana sebelum Muktamar Situbondo

\footnotetext{
${ }^{16}$ Kacung Marijan, Quo Vadis NU Setelah Kembali ke Khittah 1926 (Jakarta: Erlangga, 1992), 214.
} 
dilakukan. Banyak kalangan memandang dampak dari munculnya netralitas NU adalah munculnya kecenderungan dari pemerintah terutama dari kalangan Golkar- yang melihat perilaku tersebut sebagai peluang untuk mendekati NU secara lebih serius. Kecenderungan tersebut didasarkan pada kedekatan beberapa kalangan Muda dari kelompok Abdurrahman Wahid yang dipandang memiliki visi yang sama dengan pemerintah, terutama terkait dengan Pancasila dan kebijakan kembali ke Khittah sebelum keputusan Muktamar Situbondo dipaparkan. Berdasarkan kecenderungan tersebut, keberadaan kalangan Muda NU sebelum naik ke tampuk pimpinan di NU juga telah mendapat dukungan dari pemerintah. ${ }^{17}$

Munculnya perilaku politik akomodatif oleh NU terhadap pemerintah juga memunculkan permasalahan di kalangan NU. Hal ini muncul dalam Munas Alim Ulama dan Konbes NU di Cilacap pada tahun 1987 di mana sebagian peserta Munas merisaukan adanya fenomena perilaku politik di kalangan ulama yang dipandang bertentangan dengan nilai-nilai Islam. Munculnya konflik antar ulama NU dan basis masa pendukungnya yang sering terjadi merupakan fenomena yang berkembang dan merisaukan banyak kalangan. Menyikapi hal ini, Munas Alim Ulama di Cilacap mulai memunculkan rekomendasi untuk mempertimbangkan pentingnya menjaga tali persaudaraan dalam berpolitik, baik persaudaraan antar sesama umat lslam (ukhuwah islamiyah), antar sesama bangsa dan, se-tanah air (ukhuwah wataniyah) maupun persaudaraan antar sesama manusia (ukhuwah bashariyah). Kesepakatan Munas Cilacap tersebut juga ditindaklanjuti dalam Muktamar ke 28 di Krapyak yang memunculkan sembilan rumusan kesepakatan yang dipandang sebagai pedoman berpolitik bagi kalangan NU. ${ }^{18}$

\footnotetext{
${ }^{17}$ Martin Van Bruinessen, "Konjungtur Sosial Politik di Jagad NU Paska Khittah 26." In Gus Dur dan Masyarakat Sipil (Yogyakarta: LKiS, 1999).

18 PBNU, Lajnah Ta'li>f wa al-Nashr. "Hasil Muktamar XXVIII,." Lihat Hasil Muktamar XXVIII, Lajnah Ta'li>f wa al-Nashr, PBNU, 1996 untuk lebih
}

Dari rumusan tersebut mengindikasikan bahwa refleksi atas doktrin terhadap gerakan kembali ke Khittah masih dipandang belum memiliki rumusan yang jelas dalam ranah aplikasinya. Karena demikian, rumusan pedoman politik ini dimunculkan sebagai upaya untuk rnemperjelas wilayah gerakan politik kultural yang dikehendaki oleh NU secara kelembagaan dengan wilayah politik praktis. Selain itu, Muktamar Krapyak juga memunculkan beberapa kritikan dari beberapa kalangan NU yang merisaukan hubungan Abdurrahman Wahid-sebagai ketua PBNUyang dinilai terlalu dekat dengan Golkar. Beberapa kalangan NU menilai bahwa perilaku Abdurrahman Wahid tersebut tidak sesuai dengan kesepakatan Situbondo. Bahkan keterlibatannya dengan kalangan LSM -yang sering menjalin hubungan dengan kelompok nonmuslim dan sering melakukan perilaku kontroversial, juga telah mendatangkan kritik dari kalangan kyai konservatif. Karena demikian, perilaku kontroversial Abdurrahman Wahid tersebut selain menimbulkan konflik internal dikalangan NU juga menimbulkan permasalahan dalam menentukan batas-batas pemaknaan Khittah 1926. Atas dasar perilaku tersebut, isu pelengseran Abdurrahman Wahid mulai banyak bermunculan terutama sebelum Muktamar Krapyak diselenggarakan. Namun sebaliknya, keputusan Muktamar Krapyak pada akhirnya tetap mendukung Abdurrahman Wahid sebagai ketua PBNU untuk periode 1997-1994. ${ }^{19}$

Sebagaimana Muktamar sebelumnya, duet Abdurrahman Wahid - K.H. Ahmad Shiddiq dipandang sebagai kemenangan kelompok muda NU yang dikenal dengan kelompok progresif atas kelompok tua konservatif. Beberapa ide pembaharuan yang dihasilkan dalam periode sebelumnya mulai mendapat respon positif meskipun dalam implementasi program banyak menimbulkan krtitik. Karena demikian, peserta Muktamar pada akhirnya dapat memahami bahwa komposisi kepengurusan pada periode sebelumnya tidak kondusif

jelas terhadap hasil rumusan etika berpolitik tersebut. (Jakarta, 1996).

19 Greg Barton dan Greg Fealey, Tradisionalisme Radikal persinggungan Nahdlatul Ulama-Negara (Yogyakarta: LKiS, 1997), 52. 
bagi implementasi program yang telah dirumuskan dalam Muktamar Situbondo. Oleh karenanya, konsolidasi internal dan pemilihan komposisi pengurus yang kohesif dijadikan prioritas oleh peserta muktamar sebagai upaya memperbaiki program berikutnya. Tim formatur hasil kesepakatan Situbondo selanjutnya memunculkan komposisi kepengurusan yang terdiri dari kelompok Abdurrahman Wahid, seperti Gaffar Ramlan, yang dikenal sebagai orang yang dinamis, sekaligus teman lamanya di Jawa Timur yang dipilih sebagai Sekretaris Jenderalnya. Sementara Ma'ruf Amin, seorang ulama dari Banten terpilih sebagai Katib shuriyah. Sedangkan Chalid Mawardi-sekutu Idham Chalid yang menjadi pesaing kubu Abdurrahman Wahid - terpilih sebagai salah satu dari lima wakil ketuanya. Sementara pada tingkat Shuriyah, dipilih K.H. Sahal Mahfudz, salah seorang tokoh kyai dari kalangan LSM di Jawa Tengah, beserta K H. Ali Yafie. Sedangkan KH.R. As'ad Syamsul Arifin, terpilih sebagai Mustashar. ${ }^{20}$

Berbeda dengan adaptasi kelembagaan setelah Muktamar di Situbondo, menjelang 1990-an, perilaku politik NU mulai ditandai dengan adanya ketegangan antara NU dengan Golkar (pemerintah), hal yang selanjutnya mendorong timbulnya keinginan politisi NU untuk terlibat secara langsung dalam perebutan kepemimpinan di PPP, namun dalam perkembangannya, mereka mengalami hal yang sama sebagaimana politisi NU yang ada di Golkar. Sikap politisi NU ini berbeda dengan yang dikehendaki oleh kalangan struktural NU yang mulai menunjukkan sikap apolitis baik terhadap PPP maupun Golkar. Terkait dengan perilaku apolitis tersebut mengindikasikan bahwa meskipun menjelang pemilu 1992 telah muncul gerakan "kembali ke kandang" yang dilakukan kalangan politisi NU ke dalam PPP, namun secara kelembangan, NU tetap menunjukkan sikap netralitas terhadap semua partai politik. Hal tersebut terlihat pada munculnya surat edaran

20 PBNU, Lajnah Ta' Tif wa al-Nashr. Hasil-hasil Muktamar ke-29 Nahdlatul Ulama Krapyak, Yogyakarta 1987. (Jakarta: PBNU, Lajnah Ta'Tif wa alNashr, 1987). yang dikeluarkan oleh PBNU kepada kalangan pengurus hariannya yang menegaskan untuk tidak diperbolehkan menjadi calon atau dicalonkan sebagai anggota legilatif partai kecuali bersedia mundur dari kepengurusan NU. Oleh karena itu, pada era 90-an, kondisi politik di Indonesia terutama menjelang pemilu 1992 dikenal sebagai bentuk buram dari dinamika politik NU yang tercermin dari banyaknya kalangan NU yang tergeser di partai politik secara structural. ${ }^{21}$

Munculnya ketegangan antara NU dengan pemerintah dalam periode ini terlihat dari pernyataan Abdurrahman Wahid dalam pertemuan Rapat Akbar dan Istighathah NU di Jakarta pada tahun 1993 yang banyak mengkritisi beberapa kebijakan pemerintah, terutama dalam keterlibatan pemerintah dalam pembentukan ICMI yang dipandang sarat politis dan bernuansa primordialistis. Bersamaan dengan itu, Abdurrahman Wahid juga menyatakan secara tegas menolak mendukung pencalonan Suharto sebagai presiden dalam pemilu berikutnya. Hal tersebut ditambah lagi dengan keterlibatannya sebagai ketua Pokja Forum Demokrasi, di mana hal tersebut semakin menambah ketegangan yang terjadi-di mana posisinya sebagai ketua umum PBNU dipandang bias dan memiliki pengaruh yang luas. ${ }^{22}$

Karena munculnya ketegangan antara pemerintah dengan kalangan NU ini, kuatnya campur tangan pemerintah dalam proses Muktamar Cipasung (1984) juga mulai dirasakan oleh beberapa peserta Muktamar. Hal tersebut terindikasi dengan adanya rencana pemerintah yang menghendaki agar kelompok Abdurrahman Wahid tidak terpilih kembali sebagai pengurus PBNU pada periode berikutnya. Hal tersebut juga terlihat dalam pernyataan Abdurrahman Wahid dalam menyampaikan pertanggungjawaban kepengurusannya, di mana secara eksplisit menyinggung adanya keterlibatannya pihak luar dalam

\footnotetext{
${ }^{21}$ Saleh Al. Djufri, "Hentikan Karantina Politik Bagi NU." In NU Khittah dan Godaan Politik, by Sinansari Ecip. (Bandung: Mizan, 1994).

22 Greg Barton dan Greg. Fealey, Tradisionalisme Radikal persinggungan Nahdlatul Ulama-Negara. (Yogyakarta: LKiS, 1997).
} 
proses Muktamar, oleh karenanya ia menyatakan bahwa NU memiliki karakter tersendiri dalam mengimplementasikan demokrasi. Meskipun proses Muktamar Cipasung banyak dipengaruhi oleh beberapa kepentingan-terutama pemerintah, proses Muktamar pada ahirnya dapat berjalan sesuai keinginan dan harapan mayoritas peserta Muktamar. ${ }^{23}$

Dinamisasi kepemimpinan hasil Muktamar tersebut tetap memunculkan KH. Ilyas Ruchyat sebagai Ketua Rais Aam dan Abdurrahman Wahid sebagai Ketua Tanfiziyah untuk periode 1994-1999. Meskipun demikian, untuk merumuskan kepengurusan periode ini juga ditandai dengan alotnya kesepakatan yang dibentuk oleh tim formatur hasil Muktamar Cipasung. Di antara faktor yang muncul adalah karena salah seorang dari lima anggota tim tersebut tidak bersedia untuk menandatangani-karena usulannya untuk menjadikan Abu Hasan dalam kepengurusan PBNU tidak disetujui oleh keempat anggota tim lainya. Meskipun demikian, kepengurusan PBNU pada ahirnya tetap terbentuk dengan komposisi tetap menolak memasukkan nama Abu Hasan dalam kepengurusan PBNU, di antara nama yang masuk dalam kepengurusan ini adalah Fahmi Syaifuddin yang menjadi salah satu rival utama Abdurrahman Wahid dalam Muktamar diposisikan menjadi salah satu ketua di tanfiziyah. ${ }^{24}$

Beberapa kalangan memandang bahwa komposisi kepengurusan PBNU periode ini terdiri dari kalangan yang tidak didukung oleh pemerintah. Hal tersebut terlihat dari penolakan Presiden Suharto terhadap komposisi kepengurusan hasil Muktamar Cipasung sebelumnya. Dari munculnya penolakan pemerintah tersebut, fenomena yang muncul kemudian adalah terbentuknya Koordinasi Pengurus Pusat Nahdlatul Ulama (KPPNU), yang kemudian dikenal dengan "PBNU tandingan". KPPNU tersebut dibentuk oleh Abu Hasan, salah seorang rival utama Abdurrahman Wahid yang didukung kuat oleh Presiden Suharto (Pemerintah). Meskipun

\footnotetext{
23 Fealey, Tradisionalisme Radikal persinggungan Nahdlatul Ulama-Negara.

${ }^{24}$ PBNU, Lajnah Ta' Iif wa al-Nashr. "Hasil Muktamar XXVIII,." Lihat Hasil Muktamar XXVIII, PBNU, Lajnah Ta'Tif wa al-Nashr, 1996 untuk lebih jelas terhadap hasil rumusan etika berpolitik tersebut.
}

keberadaan KPPNU telah menimbulkan ketegangan di antara kalangan NU dengan kelompok Abu Hasan, Abdurrahman Wahid tidak mempermasalahkan secara hukum keberadaan KPPNU yang dibentuk oleh Abu Hasan. Bahkan dalam perkembangan selanjutnya, beberapa nama Kyai yang dicantumkan dalam KPPNU mulai mempermasalahkan Abu Hasan, di mana hal tersebut menyebabkan keberadaan KPPNU tidak pernah dihiraukan oleh kalangan Ulama NU lainnya.

Ketegangan yang muncul sejak Muktamar di Cipasung terus berlangsung hingga Muktamar di Lirboyo pada tahun 2000. Namun dalam periode ini, adaptasi kelembagaan politik di NU diawali dengan munculnya situasi yang terkait dengan semakin memanasnya suhu perpolitikan di Indonesia secara umum. Situasi tersebut diawali dengan munculnya beberapa konflik dan kekerasan di beberapa daerah. Di antara penyebab dari kekacauan politik yang muncul tersebut adalah terkait dengan adanya krisis ekonomi di Indonesia, di mana hal tersebut juga mengakibatkan lengsernya Suharto dari kepresidenan.

Menyikapi beberapa konflik dan kekerasan yang terjadi, NU secara kelembagaan lebih banyak melakukan konsolidasi dan dialog antar tokoh-tokoh agama dan masyarakat. Melalui pernyataan sikap dan pandangannya terhadap situasi tersebut, PBNU menghimbau kepada kalangan NU agar tetap menjaga persatuan dan kesatuan Bangsa. ${ }^{25}$ PBNU juga melakukan konsolidasi di antara tokoh-tokoh masyarakat, melalui Ketua PBNU Abdurrahman Wahid beserta beberapa tokoh masyarakat dalam pembentukan kelompok Ciganjur, di mana selanjutnya menghasilkan kesepakatan bersama yang dikenal dengan "Deklarasi Ciganjur". Untuk mendukung hasil kesepakatan tersebut, PBNU juga mengeluarkan surat instruksi yang berisi himbauan terhadap seluruh lapisan masyarakat NU untuk

\footnotetext{
25 A. Muqsith Ghazali dan Suwendi. Marzuki Wahid, Dinamika NU, perjalanan sosial dari Muktamar Cipasung (1991) ke Muktamar Kediri (1999). (Jakarta: Kompas dan LAKPESDAM, 1999).
} 
turut aktif mendukung deklarasi yang dipandang sebagai agenda reformasi. ${ }^{26}$

Perubahan dinamika politik di Indonesia tersebut juga ditandai dengan munculnya beberapa partai politik. Terkait dengan fenomena tersebut, PBNU banyak rnenerima usulan dari beberapa Cabang NU di daerah yang menghendaki agar NU terlibat kembali dalam partai politik. Sementara di sisi lain, juga muncul perdebatan tentang konsistensi atas keputusan Khittah sebagai respon dari usulan pembentukan partai tersebut. Menyikapi hal tersebut, dalam rapat harian yang dihadiri oleh Shuriyah dan Tanfiziyah PBNU pada tanggal 3 Juni 1998, PBNU membentuk tim lima untuk merespon fenomena yang terjadi, di mana setelah melakukan beberapa pertemuan, selanjutnya tim tersebut menyepakati untuk membentuk partai politik yang kemudian meyerahkan hasil rumusannya kepada Shuriyah dan Tanfiziyah dalam rapat harian pada tanggal 22 Juli 1998. Menindak lanjuti hasil kesepakatan tersebut, pada tangal 23 Juli 1998, dilakukan deklarasi partai dengan nama "Partai Kebangkitan Bangsa". ${ }^{27}$

Dengan munculnya deklarasi yang difasilitasi oleh PBNU, beberapa politisi NU lainnya memunculkan kritik di mana dalam perkembangannya telah menimbulkan prokontra terhadap keberadaan partai yang difasilitasi PBNU. Menyadari hal tersebut, PBNU mengeluarkan instruksi agar fungsionaris NU di segala jenjang kepengurusan tidak merangkap jabatan dengan kepengurusan di PKB atau partai politik lainnya. Dari fenomena munculnya PKB yang direkomendasikan NU sebagai partai politiknya, secara tidak langsung telah merubah paradigma kalangan NU dalam memaknai kesepakatan Situbondo, meskipun kebijakan PBNU dengan mempertegas kepengurusan

26 Greg Barton, Abdurrahman Wahid, Muslim Democrat, Indonesian President (Sydney: UNSW, 2002), 285.

${ }^{27}$ DPW. PKB, Dokumen Deklarasi Partai Kebangkitan Bangsa. DPW PKB Jawa Timur, Dokumen deklarasi Partai Kebangkitan bangsa, hal. 122. (Surabaya: DPW PKB Jawa Timur, 1999). antara partai politik dan NU tetap diberlakukan. Perdebatan atas pembentukan partai tersebut terus mengemuka terutama menjelang Muktamar XXX diselenggarakan. Dalam Muktamar XXX di Lirboyo, meskipun telah muncul perdebatan tentang konsepsi kembali ke Khittah 1926, para peserta tidak banyak mempersoalkan posisi Abdurrahman Wahid yang dipahami tidak bertentangan dengan pemaknaan Khittah, karena sebagian besar peserta menyadari bahwa posisi Abdurrahman Wahid sudah non aktif di PBNU. Begitu pula dalam laporan pertanggung-jawababannya tentang progam yang telah dilakukan, peserta Muktamar tidak banyak melakukan kritik secara serius sebagaimana dalam Muktamar Cipasung sebelumnya yang diliputi dengan ketegangan dan pertentangan.

Perubahan yang muncul dari hasil Muktamar Lirboyo itu adalah terpilihnya K.H Sahal Mahfudz sebagai Rāis ' $\bar{A} m$ dan K.H. Endin Fachruddin Masturo sebagai wakilnya, sementara K.H. Hasyim Muzadi terpilih sebagai ketua Tanfiziyah menggantikan Abdurrahman Wahid. Selain perubahan kepemimpinan, Muktamar juga memberikan rekomendasi politik tentang anjuran terhadap warga NU untuk tetap menggunakan hak politinya secara bebas, kritis dan rasional sesuai dengan prinsip-prinsip yang disepakati dalam Muktamar Krapyak (1987). Selain itu peserta Muktamar juga menyepakati untuk tetap menjadikan NU sebagai organisasi sosial keagamaan, namun demikian, peserta Muktamar juga menghendaki NU untuk tetap bersikap kritis terhadap dinamika partai politik yang sering menggunakan nama NU. Oleh karenanya dalam periode terbentuk komisi politik yang digunakan untuk mengontrol partai-partai politik yang dianggap sebagai penyalur aspirasi warga NU. ${ }^{28}$

\section{b. Dinamisasi Doktrin Teologis: Kittah NU 26 dan Interpretasinya}

Dinamisasi kepemimpinan di tubuh NU secara kelembagaan juga berpengaruh

\footnotetext{
${ }^{28}$ Sekretariat Jenderal. PBNU, "Hasil Muktamar XXX Nahdlatul Ulama." (Jakarta: Sekretariat Jenderal PBNU, 2000), 185.
} 
terhadap perubahan paradigma dalam merespon perubahan yang terjadi. Hal ini dapat ditelusuri lebih lanjut pada aspek penafsiran doktrin keagamaan yang di perdebatkan oleh para kyai dan di NU. Beberapa indikator penting yang dapat dilihat dalam kesepakatan Situbondo misalnya adalah terkait dengan penerimaan NU terhadap Pancasila, dan keputusan untuk kembali ke Khittah 1926 yang berimplikasi terhadap terlepasnya NU dari politik secara formal kelembagaan. Kedua indikator tersebut merupakan faktor penting yang menyebabkan NU bersikap lebih akomodatif terhadap pemerintah, di mana secara teologis, Pancasila di pandang memiliki nilai-nilai mașlahah. Dalam konteks Indonesia, Pancasila berfungsi sebagai mithāq atau kesepakatan antara umat Islam dengan golongan lain sebagaimana yang dimaksudkan pada penafsiran Alquran surah Al-ra'd ayat 20. Keberadaan negara Indonesia dalam pengertian ini bertujuan untuk mencapai persatuan dalam berbangsa dan bernegara, karena demikian, Pancasila juga berfungsi sebagai Kalimātin Sawā'in yang menyatukan seluruh segmen masyarakat Indonesia. Atas dasar penafsiran seperti itu, maka pada kesepakatan Situbondo diputuskan untuk menerima Pancasila sebagai ideologi organisasi secara kelembagaan. ${ }^{29}$

Penerimaan Pancasila sebagai ideologi NU memiliki pengaruh politis cukup signifikan terutama terhadap pandangan pemerintah yang selama ini memposisikan NU sebagai oposisi radikal. Keinginan pemerintah yang menghendaki seluruh ormas di Indonesia untuk menjadikan Pancasila sebagai ideologi mendapat respon positif bagi NU, karena demikian, refleksi doktrin yang dilakukan NU terhadap penerimaan pancasila juga dipandang sebagai penyebab munculnya perilaku akomodatif NU terhadap pemerintah. Perilaku akomodatif tersebut dapat ditelusuri pada dimensi doktrin politik sunni terutama pada landasan normatifnya (figh) yang menurut beberapa kalangan merupakan faktor dominan yang mempengaruhi kebijakan akomodasi dalam periode ini.

29 Faisal Ismail, ldeologi, Hegemoni dan Otoritas Agama: Wacana Ketegangan Kreatif Agama dan Pancasila (Yogyakarta: Tiara Wacana, 1999), 237.
Sebagaimana yang dibahas sebelumnya, politik sunni menekankan pada prinsip menghindarkan dimensi madarat (dampak negatif). Dalam tinjauan praksis, para politisi NU menganggap bahwa diskrimansi politik yang terwujud dalam kebijakan de-NU-nisasi di tubuh internal PPP merupakan alasan mendasar dari perubahan orientasi tersebut. Pada aspek lain, beberapa kalangan NU melihat bahwa keberadaan NU di PPP selama ini dinilai tidak memiliki aspek maslahat (dimensi positif), sebaliknya, pandangan pemerintah terhadap NU sebagai rival politik secara serius juga dipandang telah merugikan posisi NU secara kelembagaan. Atas dasar pemaknaan praksis tersebut, berawal dari keputusan kembali ke Khittah 1926 yang selanjutnya memunculkan sikap akomodatif NU terhadap pemerintah, maka perubahan tersebut merupakan refleksi yang didasarkan pada upaya menghindari dimensi madarat sebagaimana terumuskan dalam kaidah fiqh, bahwa dar' al-mafásid muqaddam 'ala jalb almașālih.

Dalam pemaknaan selanjutnya, secara teologis NU menyikapi praksis politik tersebut dengan mengalihkan dukungan politik kulturalnya pada Golkar (pemerintah). Pemaknaan terhadap realita politik ini dapat ditelusuri dalam pertemuan Baḥthul Masāil yang dilakukan oleh Pondok Pesantren se-D.I.Y yang menghasilkan keputusan bahwa pada pemilu 1987, Golkar merupakan partai yang pantas untuk dipilih atas dasar manfaat yang diperoleh serta atas dasar konsep ketaatan pada ulil-amri (D.I.Y. 1987). Meskipun pertemuan tersebut belum mewakili NU secara kelembagaan, Namun hasil keputusan yang dirumuskan banyak mewarnai situasi menjelang pemilu 1987 - di mana para politisi NU banyak menggunakan hasil keputusan tersebut sebagai landasan keberpihakan mereka kepada Golkar. Dengan demikian, sikap akomodatif NU terhadap pemerintah tersebut dipandang sebagai bentuk dari pemahaman konsep akhaffu al-ḍararain, yang dimaksudkan bahwa pilihan terhadap Golkar dipandang lebih efektif dan memiliki resiko kecil dari pada pilihan terhadap kedua 
partai politik lainnya. Oleh karenanya, hal ini telah menyebabkan munculnya gerakan penggembosan di tubuh PPP menjelang pemilu 1987 - hingga berdampak merosotnya perolehan suara PPP pada hasil pemilu. ${ }^{30}$

Sikap akomodatif ini terus berlangsung hingga berlangsungnya Muktamar NU di Krapyak Yogyakarta. Dalam Muktamar tersebut tidak dimunculkan perubahan secara signifikan atas interpretasi Khittah sebagaimana yang dibahas pada Muktamar Situbondo. Untuk mencapai tujuan keagamaan, peserta Muktamar masih tetap memaknai gerakan politik kultural lebih strategis dan lebih bermanfaat dari pada terlibat pada politik praktis. Sebaliknya, beberapa refleksi atas Khittah mulai mengalami pemaknaan secara lebih spesifik, sebagaimana yang terumuskan pada sembilan pokok etika berpolitik dalam NU - yang mencerminkan batasan-batasan tegas antara wilayah politik praktis dan gerakan kultural. Secara kelembagaan, periode ini juga meluncurkan penegasan terhadap implementasi doktrin gerakan kultural yang berorientasi ke arah sosial dan keagamaan. Hal ini ditandai dengan semakin intensifnya hubungan yang dilakukan NU dengan Golkar (pemerintah) serta kalangan pengusaha, termasuk dari kalangan Cina. Upaya melibatkan NU secara kelembagaan dalam menjalin hubungan kerjasama dengan para pengusaha Cina dalam pendirian BPR, serta implementasi program pendidikan dan kesehatan yang berlangsung di beberapa daerah. $^{31}$

Secara ideologis dan normatif, sikap akomodatif NU terhadap pemerintah dalam periode ini menemukan titik temu dalam strategi implementasinya. Meskipun NU memandang rezim orde baru sebagai pemerintahan dari rezim yang militeristik. ${ }^{32}$ Namun pilihan akomodatif NU terhadap pemerintah tetap terlihat dalam sikap politik NU yang diupayakan sebagai bentuk

\footnotetext{
${ }^{30}$ D. F. Anwar, Militer dan Polilik di Indonesia: Sebuah T'injauan (Jakarta: Masyarakat Indonesia, 1983).

31 Afan Gaffar, "NU dan PPP Pasca Muktamar." In NU Khittah dan Godan politik, by S. Simaruasri Ecip (Bandung: Mizan, 1994), 64.

32 Nawaz Mody, B. Indonesia under Suharto. (Bangalore: Sterling, 1987).
}

menghindari resiko negatif dari rezim Suharto. Sebagaimana periode sebelumnya, maka sikap akomodatif ini juga dipahami sebagai upaya menghilangkan ketegangan yang terjadi antara NU dan pemerintah. Sebaliknya, sikap oposisi dengan pemerintah dipahami akan menimbulkan sikap represif pemerintah yang muncul dalam bentuk kekerasan, sebagaimana yang terjadi pada kasus Tanjung Priok dan kasus-kasus lainnya. Karena demikian, sesuai dengan prinsip ideologi politik Sunni, bentuk-bentuk kekerasan dalam segala situasi dan kondisi harus selalu dihindari. Sedangkan pada dimensi pragmatis, perilaku akomodatif dengan pemerintah selain diharapkan akan memunculkan situasi baru yang mengarah pada tercapainya tujuan-tujuan pragmatis NU - seperti adanya orang-orang NU di birokrasi pemerintahan, mengalirnya dana-dana bantuan dari pemerintah dalam pendidikan, pesantren atau di bidang ekonomi - namun juga diharapkan berdampak pada berubahnya pandangan pemerintah terhadap NU yang selama ini dianggap oposisi radikal.

Konsistensi untuk tetap Khittah selama ini bagi NU secara kelembagaan juga diimplementasikan dengan menanggapi dinamika politik secara apolitis terhadap dinamika persoalan politik praktis. Perilaku yang dimunculkan kalangan struktural NU tersebut mengindikasikan adanya upaya memperkuat konsistensi Khittah secara kelembagaan. Disisi lain, sikap apolitis tersebut juga memunculkan ketegangan antara NU dengan Golkar (pemerintah) di mana kemudian banyak berpengaruh pada pola hubungan NU secara kelembagaan dengan pemerintah. Secara teologis, beberapa respon NU, sebagaimana yang dikemukakan Abdurrahman Wahid dalam Rapat Akbar dan Istighathah pada tahuan 1993, terlihat menghendaki adanya bentuk negara yang tetap konsisten pada pancasila, sementara yang dilakukan pemerintah justru sebaliknya, upaya pemerintah dengan merangkul gerakan politik Islam telah memunculkan dominasi agama atas negara. Dalam hal ini, upaya yang dilakukan pemerintah dalam mendukung Islam politik tersebut dipahami oleh kalangan NU sebagai bentuk politisasi agama yang digunakan pemerintah terhadap ormas Islam 
sebagai alat legitimasi politik. Oleh karena itu, upaya pemerintah ini secara normatif juga bertentangan dengan pandangan politik NU di mana dominasi agama tertentu atas agama yang lain bertentangan dengan filosofi Pancasila yang mendudukkan semua agama dan golongan secara sama, sebagaimana yang telah dibahas dalam Muktamar Situbondo sebelumnya.

Di antara faktor lainnya yang menjadikan NU terlihat bersikap responsif dan oposisi terhadap pemerintah adalah keterlibatan pemerintah dalam Muktamar Cipasung serta dukungannya terhadap kelompok Abu Hasan yang dipandang telah menghilangkan ruang kebebasan bagi kalangan NU. Campur tangan pemerintah tersebut merupakan salah satu upaya pemerintah dalam melakukan kontrol terhadap kalangan lslam agar dapat memberikan dukungan secara politis. Pada saat yang sama, sikap responsif dan oposisi kalangan NU ini juga didasarkan pada pemaknaan pragmatis politik, di mana NU secara kelembagaan tidak mendapatkan tujuan-tujuan pragmat is terutama dalam bentuk bantuan di bidang ekonomi maupun pendidikan yang menurun secara drastis jika dibanding pada periode sebelumnya.

Meskipun hubungan NU dengan pemerintah cenderung oposisi dalam periode ini, pada tataran kelembagaan konflik dan oposisi dengan pemerintah tidak diimplementasikan NU secara radikal. Diantara kebijakan NU yang diwujudkan melalui penguatan internal kelembagaan dikalangan NU adalah melalui upaya membentuk komunikasi antara kalangan NU dengan pemerintah. Meskipun demikian, upaya ini baru berhasil dua tahun kemudian yakni dalam pertemuan di pondok pesantren Genggong Probolinggo pada tahun 1996. ${ }^{33}$ Dari pertemuan di Genggong tersebut menunjukkan bahwa oposisi dengan pemerintah dalam pandangan teologi politik NU masih tetap dalam batasan-batasan wajar dan tidak bertentangan dengan hukum negara. Bahkan dalam pertemuan tersebut, pendekatan personal lebih terlihat daripada pendekatan kelembagaan, di mana secara simbolik keberadaan NU telah terwakili dengan peran

\footnotetext{
33 Barton, Abdurrahman Wahid, Muslim Democrat, Indonesian President.
}

Abdurrahman Wahid dalam pertemuannya dengan Presiden Suharto.

Interpretasi atas doktrin teologi politik NU ini berbeda pada saat Abdurrahman Wahid terpilih menjadi Presiden Indonesia pada tahun 1999. Hal ini pula yang terlihat dalam proses Muktamar di Lirboyo di mana hasil Muktamar tersebut mencerminkan sikap akomodatif NU terhadap pemerintahan Abdurrahman Wahid. Penerimaan tersebut secara teologis dapat dipahami karena baik dari aspek pragmatis, normatif maupun ideologis berkesesuaian dengan paradigma NU mengharuskan bagi kalangan NU untuk berperilaku akomodatif. Hal tersebut terlihat dari belum banyaknya sikap kritis dan perdebatan di kalangan NU dalam politik yang diambil oleh pemerintah. Beberapa isu kontroversial yang terkait dengan perilaku Abdurrahman Wahid juga sedikit disinggung dalam muktamar ini. Namun setelah muktamar diselenggarakan, beberapa isu kontroversial yang terkait dengan perilaku Abdurrahman Wahid telah memunculkan kritik dan konflik dari beberapa politisi yang ada di DPR di mana sikap tersebut selanjutnya semakin terlihat menjelang dilaksanakannya sidang umum MPR. Munculnya perilaku kritis dan oposisi ini juga menimbulkan pertentangan di kalangan NU, yakni antara mendukung atau tetap konsisten dalam jalur NU Khittah, dengan tetap menjadikan NU sebagai organisasi sosial keagamaan.

Munculnya fenomena ini juga memunculkan perdebatan pada aspek doktrin teologis. Munculnya perilaku akomodatif NU terhadap Abdurrahman Wahid yang terlihat sejak awal kepemimpinannya, semakin terlihat pada saat konflik berlangsung, di mana kalangan politisi NU menyadari bahwa secara pragmatis dan normatif NU secara kelembagaan akan dirugikan. Sementara disisi lain, beberapa kalangan struktural NU tetap mendukung konsistensi terhadap Khittah 1926, meskipun secara pragmatis politik dengan turunnya Abdurrahman Wahid juga akan berpengaruh terhadap aspek pragmatisme NU secara kelembagaan. Berkaitan dengan munculnya perdebatan tersebut, PBNU sendiri, melalui K.H. Hasyim Muzadi beserta tokoh NU lainnya lebih banyak melakukan 
pendekatan personal melalui safari politiknya. Dengan didampingi oleh pengurus PBNU lainnya, safari tersebut bertujuan untuk meredam kemarahan warga NU yang mulai banyak bermunculan dalam bentuk demonstrasi dan ketegangan yang terjadi di lapisan masyarakat bawah. Karena demikian, meskipun dalam perkembangannya Abdurrahman Wahid pada akhirnya tergusur dari kepresidenan, upaya yang dilakukan PBNU dalam melakukan kunjungan ke daerah-daerah dan safari politik pada akhirnya dapat meredam terjadinya konflik secara besar.

\section{c. Dinamisasi Program Praksis NU: dari Pemberdayaan ke Advokasi}

Dinamisasi yang muncul baik dalam bentuk kepemimpinan dan doktrin sebagaimana yang diuraikan sebelumnya, juga bekonsekuensi terhadap perubahan arah pengembangan program yang akan dilaksanakan. Terbentuknya pola kedekatan yang dilakukan di kalangan NU dengan pemerintah setelah Muktamar NU di Situbondo 1984 telah memunculkan hubungan sikap ako modatif NU secara kelembagaan. Beberapa kalangan menyadari bahwa kondisi ini berbeda dengan periode sebelumnya, di mana NU dianggap rival politik pemerintah yang sering bersikap oposisi secara radikal. Arah gerakan NU kemudian mulai menekankan pada aspek pendidikan, sosial dan kemasyarakatan. Beberapa program yang bersifat pemberdayaan masyarakat mulai bermunculan, begitu juga pembentukan lembaga (lajnah) yang menangani program tersebut, seperti munculnya Lembaga Pengembagan dan Pembangunan pertanian NU, Lembaga Pengarang dan Penterjemah (Lajnah ta'lif wa alNashr), serta Lembaga Kajian dan Pengembangan Sumberdaya Manusia (Lakpesdam). ${ }^{34}$

Salah satu rekomendasi penting dari Muktamar Situbondo adalah program peningkatan kepedulian sosial (Shu'un alijtimaiyah), di mana selanjutnya ditindaklanjuti oleh Lembaga Kajian dan Pengembangan Sumberdaya Manusia (Lakpesdam-

\footnotetext{
${ }^{34}$ Mitsuo Nakamura, Agama dan Perubahan Politik di Indonesia: Tradisionalisme Radikal (Surakarta: Hapsara, 1982), 23-24.
}

NU) melalui bidang pengembangan ekonomi masyarakat di beberapa wilayah seperti Lombok, Sulawesi Selatan dan beberapa daerah di Jawa. Selain memberikan pelatihan, program tersebut juga memberikan beberapa proyek percontohan. Program tersebut juga diarahkan kepada beberapa produsen kecil dalam bidang kerajinan, pertanian semi-tradisional, serta petani tambak. Program lain yang dikembangkan adalah pemberian suntikan modal kecil (revolving fund) dengan memilih teknologi sederhana, dan relatif murah (traditional plus) namun memilki manfaat yang besar. ${ }^{35}$

Program lainnya adalah di bidang pendidikan yang berupaya meningkatkan kualitas dan perbaikan manajemen. Dalam perkembangannya, di bidang ini banyak menerima dukungan dari pemerintah, sebagaimana yang telah dilaporkan dan dikaji oleh beberapa kalangan tentang ini. Berbeda dengan sebelum tahun 1984, di mana banyak madrasah dan pendidikan di kalangan NU yang menyembunyikan identis ke-NU-annya karena merasa khawatir mendapatkan perlakuan diskriminatif dari pemerintah, namun dalam periode ini, melalui Lembaga Pendidikan Maarif (L.P. Ma'arif-NU), telah banyak menerima pendaftaran dari beberapa madrasah dan sekolahan untuk bergabung secara struktural dengan NU. Upaya NU untuk mengembangkan pendidikan ini juga dilakukan di pesantren. Bahkan upaya pemerintah selanjutnya berupaya ingin menghilangkan pengkotak-kotakan lembaga, pendidikan terutama terhadap pesantren, yakni dengan mendukung lebih banyak materi umum agar lulusan pesantren lebih dapat berintegrasi dengan kalangan akademik dunia luar. ${ }^{36}$

Pengembangan program ini juga berlangsung hingga diselenggarakannya muktamar di Krapyak Yogyakarta pada tahun 1989. Dalam muktamar tersebut juga dibahas

\footnotetext{
35 Keputusan Muktamar NU XXVII. Keputusan Muktamar NU XXVII, Jawa Timur: pengurus NU Wilayah Jawa Timur, 1984.

${ }^{36}$ Andree Feillard, NU vis,-a-vis Negara, Pencarian Isi, Bentuk dan Makna (Yogyakarta: LKiS, 1999), 305.
} 
beberapa program yang berkaitan dengan kegiatan sosial keagamaan, dengan tidak membahas secara khusus tema-tema yang terkait dengan politik. Hal ini berbeda dengan muktamar sebelumnya yang sarat dengan perdebatan tentang dinamika politik. Meskipun muktamar Krapyak juga dihadiri beberapa pejabat dari pemerintah, serta beberapa pemimpin PPP - seperti Ismail Hasan Metarium dan Matori Abdul Djalil, di mana beberapa tokoh tersebut sempat memunculkan pembicaraan secara pribadi dengan Abdurrahman Wahid. Meskipun demikian, hal tersebut tidak mempengaruhi keputusan muktamar, di mana sebagian besar peserta tetap rnenghendaki depolitisasi NU. Dalam muktamar Krapyak juga tetap direkomendasikan adanya implementasi prograrnprogram yang terkait dengan pendidikan, ekonomi dan sosial-kemasyarakatan sebagaimana yang ada di periode sebelumnya.

Dalam periode ini, beberapa rekomendasi hasil muktamar yang menghendaki adanya upaya lebih serius terhadap sosial kemasyarakatan juga berpengaruh terhadap pola hubungan antara NU dengan pemerintah khususnya pada implementasi dan rekomendasi muktamar yang kemudian banyak terwujud dalam berbagai kerjasama yang melibatkan pemerintah. Sebagaimana periode sebelumnya, perbaikan pendidikan juga menjadi program prioritas dalam periode ini, saling pengertian dan kerjasama mulai dilakukan dalam bentuk modernisasi pendidikan. Selain itu juga mulai muncul program yang mengupayakan integrasi pesantren dengan dunia luar yang diwujudkan dalam implementasi program seperti pelaksanaan BKKBN, sanitasi dan kesehatan, perumusan kembali kurikulum dan sebagainya. Dengan membaiknya hubungan NU dengan pemerintah tersebut, kalangan pengusaha juga mulai terlibat dalam upaya pemberdayaan ekonomi dikalangan NU, seperti pendirian Bank perkreditan Rakyat (BPR) yang dilakukan atas kerjasama NU dengan kalangan Muslim Cina. ${ }^{37}$

\footnotetext{
37 Bruinessen, NU Tradisi Relasi Kuasa, pencarian Wacana Baru.
}

Sebagaimana kesepakatan hasil Muktamar di Krapyak, terdapat beberapa kesepakatan dalam muktamar Cipasung yang juga merekomendasikan beberapa program yang lebih mengintensifkan kepada pemberdayaan masyarakat. Keputusan yang dipandang baru dalam muktamar tersebut adalah adanya kesepakatan (deklarasi) tentang kepedulian dan advokasi terhadap lingkungan hidup. Sementara rumusan program lainnya adalah terkait dengan melanjutkan aspek pendidikan dan sosial keagamaan. Meskipun demikian, dalam perkembangannya, beberapa program NU lebih banyak difokuskan pada konsolidasi internal, di mana konflik antara Abdurrahman Wahid dengan Abu Hasan kemudian ditindaklanjuti dengan munculnya FKPPNU (Forum Komunikasi Putera Puteri Pendiri NU) yang banyak melakukan penggembosan secara internal di PBNU hasil Muktamar Cipasung. Karena demikian, kepungurusan duet Abdurrahman Wahid - llyas Rukhiyat selanjutnya difokuskan kepada penggalangan warga Nahdliyin di lapisan bawah. Penggalangan tersebut banyak dilakukan oleh pengurus PBNU melalui kunjungan dan ceramah dan istighathah akbar di beberapa daerah secara intens. Upaya lainnya adalah melalui pengembangan wawasan di kalangan kelompok strategis NU yang diupayakan dapat memperkuat gerakan kultural keagamaan ${ }^{38}$

Dari dinamika politik tersebut, NU masih tetap menunjukkan sikapnya untuk konsisten terhadap kesepakatan Situbondo, dengan tetap tidak terlibat dalam politik secara kelembagaan. Pandangan perilaku politik NU tersebut juga terlihat pada Munas Alim Ulama pada tahun 1997 di Nusa Tenggara Barat, di mana sejak awal munas dilaksanakan, Abdurrahman Wahid menyatakan bahwa pertemuan tersebut tidak membahas dinamika politik secara spesifik. Begitu pula dalam dinamika dan pelaksanaan munas yang dilakukan secara sederhana dan tidak dihadiri oleh para pejabat negara sebagaimana pertemuan- pertemuan NU sebelumnya. Meskipun demikian, munas di Lombok juga

\footnotetext{
38 Bruinessen, NU Tradisi Relasi Kuasa, pencarian Wacana Baru.
} 
memberikan rekomendasi politik secara umum, yakni terkait dengan persoalan KKN dan orientasi kebijakan pemerintah yang kurang menyentuh kalangan masyarakat bawah.

Upaya pengembangan program dalam periode ini juga masih tetap melanjutkan sebagaimana periode-periode sebelumnya. Dengan tetap menekankan pada aspek sosial keagamaan dan pendidikan. Meskipun demikian, karena situasi perpolitikan nasional yang mulai memanas, terutama menjelang tahun 1998 yang banyak ditandai dengan munculnya berbagai kerusuhan sosial dan konflik SARA, maka upaya NU secara kelembagaan difokuskan untuk meredam konflik sosial ini. Salah satu contoh dari upaya ini adalah munculnya kasus pembunuhan berantai dalam kasus "Ninja" dibebera daerah di Indonesia khususnya di Jawa Timur. Dalam merespon kasus ini, PBNU banyak melakukan konsolidasi internal dikalangan NU dan masyarakat - seperti menyelenggarakan beberapa Istighathah Kubro di Bandung, Jawa Barat. Dalam acara tersebut pengurus PBNU, yang diwakili KH. Ilyas Rukhyat menghimbau kepada warga NU untuk tidak terpancing dengan adanya fitnah dan isu tersebut.

Program NU secara kelembagaan dalam upaya untuk menjaga perdamaian, kerukunan dan persatuan ini juga terus digalakkan. Hal yang sama juga terjadi disaat menjelang lengsernya Soeharto sebagai Presiden di mana banyak terjadi konflik SARA dibeberapa daerah seperti Ambon, Aceh, Papua dan beberapa daerah lainnya. Begitupula disaat Abdurrahman Wahid baru terpilih, namun hampir dua tahun kemudian dilengserkan akibat suasana perpolitikkan nasional yang terus memanas. Ketua PBNU yang saat itu dipimpin oleh Hasyim Muzadi beserta tokoh NU lainnya lebih banyak melakukan pendekatan personal melalui safari politik yang bertujuan untuk meredam kemarahan warga NU yang mulai banyak bermunculan. Prokontra dalam bentuk demonstrasi dan ketegangan yang terjadi dilapisan masyarakat bawah menjadi situasi yang merisaukan semua kalangan. Karena demikian, meskipun dalam perkembangannya Abdurrahman Wahid pada akhirnya tergusur dari kepresidenan, upaya yang dilakukan PBNU dalam melakukan kunjungan ke daerah-daerah dan safari politik pada ahirnya dapat meredam terjadinya konflik secara besar yang mengancam disintegrasi bangsa.

\section{Menuju Teologi Politik Pembebasan}

Sebagaimana yang telah disinggung dalam pembahasan sebelumnya, meskipun hubungan antara agama dan politik (negara) dalam teologi NU memiliki keterkaitan yang erat, namun NU secara kelembagaan tetap membedakan antara agama dan politik dalam peran dan fungsinya. Beberapa kebijakan yang telah dimunculkan NU-terutama dengan pemisahan secara struktural kelembagaan dengan partai politik-tetap dimunculkan sejak awal kembali ke Khittah 1926 hingga periode-periode sesudahnya. Meskipun demikian, refleksi doktrin keagamaan yang berkembang di kalangan NU terhadap realitas praksis juga telah memunculkan beberapa perdebatan dalam memaknai Khittah 1926. Berdasarkan dinamika ini, terutama dalam periode 1999, kebijakan NU yang merekomendasikan partai politik mengindikasikan telah menggeser pemaknaan doktrin keagamaannya semula, di mana tujuan ideologis dan normatif keagamaan selanjutnya dipahami kalangan NU tidak hanya melalui pemisahan secara tegas antara aspek ideologis-normatif dengan pragmatis politik, namun tujuan kelembagaan perlu mempertimbangkan tujuan pragmatis politik, meskipun demikian, kedua dimensi tersebut harus terpisah secara kelembagaan, agar aspek ideologis dan normatif keagamaan tidak terkontaminasi oleh tujuan pragmat is politik.

Berdasarkan refleksi atas praksis politik yang dilakukan NU dalam periode 19842001 ini, secara teologis, refleksi politik NU secara kelembagaan lebih menghendaki paradigma pemisahan (separation) secara tegas antara politik dengan agama dalam peran dan fungsinya. Kecenderungan ini bisa dipahami karena NU secara ideologis memiliki akar pernikiran yang erat dengan teologi politik sunni - sebagimana yang telah dikemukakan oleh baik al-Ghazali maupun alMawardi, di mana kedua tokoh tersebut tidak 
mempersoalkan bentuk negara dalam paradigma politiknya. Karena demikian, varian-varian yang muncul dalam paradigma politik NU, secara teologis lebih pada pilihan pertimbangan substasialistik, rasionalistik dan realistik.

Varian substansialistik, sebagaimana yang telah disinggung dalam pembahasan sebelumnya, menekankan pada aspek isi (mind) daripada bentuk (body), oleh karenanya secara teologis orientasi politik NU tidak memunculkan keharusan terbentuknya negara Islam, namun yang lebih ditekankan adalah nilai, norma dan etika dalam negara. Hal yang sama juga terlihat dalam melakukan refleksi terhadap praksis politiknya, di mana pertimbangan yang dilakukan NU didasarkan pada dimensi realitas praksis yang terjadi-tidak dengan pertimbangan skriptualistik. Karena demikian, pertimbangan untung-rugi melalui kalkulasi maslahat dan mudarat merupakan aspek utama dalam orientasi teologis politik NU. Sementara dalam varian realistis, maka secara teologis dinamika refleksi politik NU lebih mendasarkan pada pertimbangan praksis, capaian ideal keagamaan dalam paradigma teologis NU diimplementasikan setelah dimensi praksis tidak ditemui aspek madarat.

Berdasarkan paradigma politik ini-yang memunculkan beberapa varian teologisrasionalistik, substansialistik dan realistik ada beberapa aspek yang dapat dirumuskan terkait dengan paradigma pembebasan sebagaimana yang dikonsepsikan oleh baik Asghar Ali Engineer maupun Ali Syariati yang mendasarkan pilar pembebasannya dalam bingkai pluralisme, humanisme religious, keadilan, tauhid dan toleransi, sebagaimana yang telah terurai dalam bab satu sebelumnya. Berdasarkan pilar pembebasan tersebut, yang bisa dilihat dalam varian substansialistik adalah munculnya ruang kebebasan beragama. Jaminan ini dapat ditelusuri karena varian dari orientasi perilaku politik ini hanya melihat agama sebagai nilai, etika dan norma, tanpa berupaya menjadikan agama sebagai tujuan politik. Karena demikian, kebebasan beragama, toleransi dengan menghargai agama lain akan lebih mudah dimunculkan dalam paradigma substansialistik dari pada varian formalistic - yang dimunculkan oleh paradigma integration yang berupaya menjadikan agama sebagai tujuan politiknya.

Begitu pula dalam varian realistik, di mana melalui pertimbangan kondisi realitas politik yang terjadi, akan memposisikan agama secara luwes dan fleksibel, sehingga pemaksaan dalam capaian tujuan keagamaan tidak terjadi dalam paradigma separation ini. Karena demikian, pandangan pluralisme yang memberikan ruang bagi agama lain secara sama dalam negara-akan memunculkan perilaku politik yang lebih adil daripada varian idealis. Hal ini berbeda dengan pemaknaan realitas praksis politiknya yang dimunculkan oleh varian idealis yang terlihat ahistoris-di mana unsur ideal kegamaan tidak pernah hadir dalam realitas kesejarahannya, karena yang terjadi dalam realitas politik tidak pernah sesuai dengan tujuan ideal keagamaan, sehingga upaya realisasi aspek ideal keagamaan akan memunculkan penyesuaian praksis yang didasarkan pada simbol ideal keagamaan.

Sebagaimana yang muncul dalam varian substansialistik, varian rasionalistik juga lebih memunculkan ruang kebebasan dalam perilaku politiknya. Hal ini terlihat pada pertimbangan yang dilakukan dalam memaknai praksis politik yang didasarkan pada pertimbangan kontekstual secara rasional. Pertimbangan untung-rugi yang menekankan pada aspek masslahat dan madarat akan memunculkan perilaku politik lebih inklusif dan toleran. Hal ini berbeda dengan paradigma integration yang memahami praksis dalam bingkai tekstual doktrin agama, maka selain memunculkan perilaku politik yang terkesan kaku dan bersifat eksklusif juga memunculkan pemaksaan teks doktrin agama terhadap praksis politik. Dimensi pembebasan lain yang dimunculkan dari varian ini, sebagaimana yang dikemukakan oleh Charless Kimball, bahwa pemunculan orientasi keagamaan secara realistis akan menghidari munculnya korupsi terhadap tujuan keagamaan. Karena pemaksaan idealitas terhadap realitas praksis akan mendorong memuculnya upaya pemaksaan tujuan idealitas terhadap 
praksis politiknya, sehingga, hal ini memunculkan pemaksaan dimensi idealitas keagamaan terhadap praksis - di mana hal ini beresiko pada terabaikannya dimensi kemanusiaan, toleransi serta bertentangan dengan pilar tauhid, pluralisme sebagaimana yang dikonsepsikan dalam pilar teologi pembebasan. Begitu juga dalam memaknai paradigma keagamaan dalam bingkai substansialis dan rasionalis, selain menghindari munculnya simbol-simbol keagamaan dalam politik. Hal ini juga menghindari munculnya konflik kepentingan dalam ranah politik atas nama agama. $^{39}$

\section{SIMPULAN}

Adanya perdebatan di kalangan NU terhadap pemaknaan Khittah 1926 yang terus berlangsung di setiap dinamisasi kelembagaannya - yang terindikasi dengan adanya beberapa varian sosiologis politik - menunjukkan adanya tarik-menarik kepentingan yang kuat yang didasarkan pada perbedaan paradigma dalam memaknai teologi politik NU. Karena demikian, evaluasi teologis dalam varian sosioiogis politik ini perlu dilihat kembali agar konstruksi teologi politik NU dapat dirumuskan secara jelas. Disamping itu juga dapat dirunut pada level mana varian sosiologi tersebut sesuai dengan bingkai paradigma politik yang membebaskan.

Salah satu varian sosiologis politik NU yang sudah dibahas sebelumnya adalah menghendaki implementasi Khittah 1926 dengan pemisahan secara tegas dari keterlibatannya dengan wilayah politik apapun. Di antara perilaku yang muncul dalam perilaku politik ini adalah pemaknaan doktrin ideologis politik NU secara ketat. Meskipun peran dan fungsi keagamaan pada varian ini relatif aman dan membebaskan, karena konflik kepentingan yang melibatkan kelembagaan NU tidak menimbulkan bias politik, namun pilihan ini terkesan minimalis - di mana hal tersebut cenderung memilih sesuatu yang baik dari buruk, tidak mencoba memilih sesuatu yang baik dari yang baik. Dominasi kekhawatiran dari seja-

39 Charles Kimball, Kala Agama Jadi Bencana (Bandung: Mizan, 2003), 25-28. rah politik NU pada periode 50-an hingga awal 80-an, telah memunculkan sindrom ketakutan bahwa ranah politik harus dihindari secara total. Atas dasar rasionalisasi ini, maka dinamika politik NU yang terjadi di setiap pemilu menjadi ajang perebutan bagi partaipartai politik, karena potensi masa yang dimilikinya tidak memiliki jalur yang dapat mengartikulasi kepentingan NU secara kelembagaan. Sebaliknya, dalam varian sosiologis politik yang merefleksikan doktrin Khittah 1926 sebagai kemunduran bagi NU secara kelembagaan, di mana selanjutnya varian sosiologis politik ini berupaya mengembalikan NU pada ranah politik, maka yang terlihat adalah kecenderungan perilaku politik oportunistik. Hal ini bisa disadari karena tujuan keagamaan lebih ditekankan pada aspek pragmatis dari pada aspek ideologis dan normatif keagamaan. Di sisi lain, bertentangan dengan varian sosiologis sebelumnya - yang terkesan membebaskan agama dari politisasi agama, maka perilaku politik dalam varian ini selain memunculkan simbol-simbol keagamaan dalam pencapaian tujuan politiknya, juga menimbulkan rentannya korupsi pada peran dan fungsi dari agama.

Sementara dalam varian sosiologis politik yang menggabungkan kedua paradigma diatas, secara historis dinamika politik NU cenderung ambivalen - yang masih terlihat tidak memberikan batasan ketegasan posisi. Hal ini dapat ditelusuri dalam realitas dinamika politik yang terjadi, di mana pemisahan secara struktural terhadap dimensi politik tidak memberikan jaminan bagi NU secara kelembagaan terbebas dari bias politik. Sehingga, fenomena ini terkesan temporal yang berlaku di saat tertentu sementara di saat yang lain cenderung berbeda, tergantung sejauh mana subjek politik mempengaruhi dan mendominasi varian sosiologis politik dalam varian ini. Selain masih rentan terhadap munculnya perdebatan terhadap batasan pemaknaan teologis di antara ketiga wilayah varian sosiologis politik ini - di mana pada setiap varian sosiologis cenderung untuk saling melakukan dominasi, pada level kepemimpin dalam tradisi NU yang figuristik, 
juga memunculkan problem terhadap perilaku politik dalam masyarakat NU. Kesadaran untuk menentukan sikap politik secara bebas nampak pupus ketika budaya patronase yang dimunculkan oleh tokoh sentral NU dalam penggunaan fatwa-fatwa politik menjelang pemilu. Meskipun fenomena ini terlihat pada varian sosiologis politik yang tidak menghendaki Khittah tanpa politik, namun dari varian lainnya, pengaruh budaya kepemimpinan ini tidak bisa dibendung di lapisan masyarakat bawah.

Berdasarkan fenomena dari ketiga varian diatas, dimensi pembebasan nampak terlihat pada varian sosiologis politik yang mendasarkan pada Khittah 1926 dengan menandaskan pemisahan secara jelas di level kelembagaan dari politik praksis, namun disisi yang lain, juga muncul dalam varian sosiologis politik yang selain mendasarkan pada Khittah 1926 namun tetap menghendaki adanya deal-deal politik yang secara historis didasarkan pada perlunya pertimbangan pragmatis. Meskipun demikian sisi negatif dan positif dari keduanya bisa terlihat di mana pemisahan tersebut menjamin pembebasan agama dari kontaminasi politik. Atas dasar pertimbangan ini, maka yang perlu dilakukan NU pada tataran teologis adalah meminimalisir bias politik pada kelembagaan NU. Ekspansi dimensi pragmat is pada level ideologis dan normatif akan memunculkan penggunaan infra dan supra struktur kelembagaan NU - baik pada aspek kepemimpinan dan program kelembagaan untuk tujuan politik. Meskipun demikian, upaya meminimalisir bias politik pada tataran teologis ini tidak dapat terealisir tanpa adanya kebijakan praksis pada level kelembagaan, terutama pada varian sosiologis yang menghendaki selain berpijak pada Khittah juga kerap rnelakukan kesepakatan-kesepakatan politik. Oleh karenannya dalam varian sosiologis politik ini, jalur politik yang telah ditentukan oleh kelembagaan NU, harus tetap dalam koridor partai, bukan melalui NU secara kelembagaan. Berdasarkan pemaknaan seperti ini, peran dan fungsi keagamaan yang menekankan pada nilai dan etika dalam politik akan tetap terjaga, dan relatif aman dari kontaminasi kepentingan politik praksis yang secara historis lebih merugikan.

\section{DAFTAR PUSTAKA}

Asghar, Ali Enginer. Islam dan Teologi Pembebasan. Yogyakarta: Pustaka Pelajar, 1999.

Anwar. D. F. Militer dan Polilik di Indonesia: Sebuah T'injauan (Jakarta: Masyarakat Indonesia, 1983).

Barton, Greg. Abdurrahman Wahid, Muslim Democrat, Indonesian President. Sydney: UNSW, 2002.

Bruinessen, Martin Van. "Konjungtur Sosial Politik di Jagad NU Paska Khittah 26." In Gus Dur dan Masyarakat Sipil. Yogyakarta: LKiS, 1999.

Bruinessen, Martin van. NU Tradisi Relasi Kuasa, pencarian Wacana Baru. Yogyakarta: LKiS, 1999.

Djufri, Saleh Al. "Hentikan Karantina Politik Bagi NU." In NU Khittah dan Godaan Politik, by Sinansari Ecip. Bandung: Mizan, 1994.

Dussel, Enrique. "a History of the Church in Latin America." In Selected Reading on Liberation Theology, by Kenneth $R$. Hall, 29. Yogyakarta: CRCS, 2003.

Fealey, Greg. Ijtihad Potitik Ulama NU, 19521967. Yogyakarta: LKiS, 1998.

Fealey, Greg Barton dan Greg. Tradisionalisme Radikal persinggungan Nahdlatul Ulama-Negara. Yogyakarta: LKiS, 1997.

Feillard, Andree. NU vis,-a-vis Negara, Pencarian Isi, Bentuk dan Makna. Yogyakarta: LKiS, 1999.

Gaffar, Afan. "NU dan PPP Pasca Muktamar ." In NU Khittah dan Godan politik, by

S. Simaruasri Ecip, 64. Bandung: Mizan, 1994.

Hikam, Mohammad A.S. Fiqh

Kewarganegaraan, Intervensi agamanegara terhadap masyarakat Sipil. Jakarta: PBPMII, 2001.

Ismail, Faisal. ldeologi, Hegemoni dan Otoritas Agama: Wacana Ketegangan Kreatif Agama dan Pancasila. Yogyakarta: Tiara Wacana, 1999.

Keputusan Muktamar NU XXVII. Keputusan Muktamar NU XXVII, Jawa Timur: pengurus $N U$ Wilayah Jawa Timur, 
1984.

Kimball, Charles. Kala Agama Jadi Bencana. Bandung: Mizan, 2003.

Marijan, Kacung. Quo Vadis NU Setelah Kembali ke Khittah 1926. Jakarta: Erlangga, 1992.

Michael Amalados. Michael Amalados, Teologi Pembebasan. Yogyakarta: Insist Press, 2001.

Mody, Nawaz. B. Indonesia under Suharto. Bangalore: Sterling, 1987.

Nakamura, Mitsuo. Agama dan Perubahan Politik di Indonesia: Tradisionalisme Radikal. Surakarta: Hapsara, 1982.
Nitiprawiro, Wahono. Teologi Pembebasan, Sejarah, Metode, Prakis dan isinya. Yogyakarta: LKiS, 2000.

PBNU. Lajnah Ta'lif wa al-Nashr. "Hasil Muktamar XXVIII,." Lihat Hasil Muktamar XXVIII, Lajnah Ta'Tif wa alNashr, PBNU, 1996 untuk lebih jelas terhadap hasil rumusan etika berpolitik tersebut. Jakarta, 1996.

PBNU, Lajnah Ta' Tif wa al-Nashr. Hasil-hasil Muktamar ke-29 Nahdlatul Ulama Krapyak, Yogyakarta 1987. Jakarta: Lajnah Ta'Tif wa al-Nashr, PBNU, 1987. 